\title{
Marco Mostert, A Bibliography of Works on Medieval Communication
}

\section{G. Matteo Roccati}

\section{(2) OpenEdition}

\section{Journals}

Édition électronique

URL : http://journals.openedition.org/studifrancesi/4278

DOI : 10.4000/studifrancesi.4278

ISSN : 2427-5856

Éditeur

Rosenberg \& Sellier

\section{Édition imprimée}

Date de publication : 1 septembre 2016

Pagination : 297

ISSN : 0039-2944

\section{Référence électronique}

G. Matteo Roccati, « Marco Mostert, A Bibliography of Works on Medieval Communication », Studi Francesi [En ligne], 179 (LX | II) | 2016, mis en ligne le 01 septembre 2016, consulté le 18 septembre 2020. URL : http://journals.openedition.org/studifrancesi/4278; DOI : https://doi.org/10.4000/ studifrancesi.4278

Ce document a été généré automatiquement le 18 septembre 2020

\section{(c) (†) $\ominus$}

Studi Francesi è distribuita con Licenza Creative Commons Attribuzione - Non commerciale - Non opere derivate 4.0 Internazionale. 


\title{
Marco Mostert, A Bibliography of Works on Medieval Communication
}

\author{
G. Matteo Roccati
}

\section{RÉFÉRENCE}

Marco Mostert, A Bibliography of Works on Medieval Communication, Turnhout, Brepols, 2012, «Utrecht Studies in Medieval Literacy» 2, XIV-658 pp.

1 Une version antérieure de cette bibliographie a paru en 1999 (voir SF XLVI, n. 138, p. 662), le présent volume en constitue la refonte considérablement enrichie (de 1580 titres elle est passée à 6843). L'introduction précise ce qu'il faut entendre par le concept moderne de "communication médiévale" et parcourt dans leurs grandes lignes les orientations de la critique sur le sujet, étudié essentiellement depuis les années 1960, en accordant une attention spéciale à l'apparition de plusieurs termes-clé (literacy, orality, pragmatische Schriftlichkeit, Verschriftlichung, ...). Elle fournit enfin un "mode d'emploi" et indique les sources dépouillées et les mises à jour en ligne prévues.

2 La bibliographie elle-même est organisée en seize chapitres. Le premier est consacré aux travaux "introductifs": Theory of Literacy and (Written) Communication, Anthropological and Sociological Contributions to the Debate, Psychological Contributions to the Debate, Linguistic Contributions to the Debate, Literacy and (Written) Communication (in the Middle Ages), The Münster School, The Freiburg School. Les autres chapitres traitent respectivement des sujets suivants: Surveys of the Introduction and Development of Written Culture (2), Forms of Non-Verbal Communication (3), Ritual (4), Language (5), Oral and Written Memory (6), Teaching, Mainly of Reading and Writing (7), Production and Use of Written Texts (8), The Preservation and Wilful Destruction of Written Texts (9), Correspondence, Messengers and the Postal System (10), Mandarin Literacy (11), The Use of Writing by Different Social Groups (12), Uses of Writing in Government, Management and Trade (13), Literature (14), Religion and Writing (15), The Symbolism of the Book (16). En général les chapitres sont articulés en de nombreuses sections, en fonction des contenus spécifiques, de l'aire 
géographique et de la période historique abordés. L'index des matières (pp. 505-593) et celui des auteurs et éditeurs modernes (pp. 595-658) complètent le volume. 